\title{
Survival strategies of freshwater insects in cold environments
}

\author{
Valeria LENCIONI
}

Section of Invertebrate Zoology and Hydrobiology, Museo Tridentino di Scienze Naturali, Via Calepina 14, I-38100 Trento, Italy e-mail address: lencioni@mtsn.tn.it

\begin{abstract}
At high latitudes and altitudes, ice formation is a major variable affecting survival of freshwater fauna and hence the abundance and composition of invertebrate communities. Freezing, but also desiccation and anoxia, are lethal threats to all life stages of aquatic insects, from the eggs to the adults. During cold periods, the aquatic stages commonly remain in or move to a portion of the water body that will not freeze or dry (e.g., deep waters of lakes, springs and hyporheic zone) where they can remain active. Less frequently they migrate to habitats that will freeze at the onset of winter. Insects have developed a complex of strategies to survive at their physiological temperature minimum, comprising (a) morphological (melanism, reduction in size, hairiness/pubescence, brachyptery and aptery), (b) behavioural (basking in the sun, changes in feeding and mating habit, parthenogenesis, polyploidy, ovoviviparity, habitat selection and cocoon building), (c) ecological (extension of development to several years by quiescence or diapause and reduction of the number of generations per year), (d) physiological and biochemical (freezing tolerance and freezing avoidance) adaptations. Most species develop a combination of these survival strategies that can be different in the aquatic and terrestrial phase. Freezing avoidance and freezing tolerance may be accompanied by diapause. Both cold hardiness and diapause manifest during the unfavourable season and: (i) involve storage of food resources (commonly glycogen and lipids); (ii) are under hormonal control (ecdysone and juvenile hormone); (iii) involve a depression or suppression of the oxidative metabolism with mitochondrial degradation. However, where the growing season is reduced to a few weeks, insects may develop cold hardiness without entering diapause, maintaining in the haemolymph a high concentration of Thermal Hysteris Proteins (THPS) for the entire year and a slow but continuous growth. A synthesis of literature regarding adaptation strategies in aquatic insects is presented, highlighting the scarcity of information on freshwater insects from Alpine regions. Most references are on Diptera Chironomidae from North America and North Europe. Some recent findings on aquatic insects from Italian Alpine streams are also presented.
\end{abstract}

Key words: freshwater insects, Chironomidae, temperature, diapause, hibernation, supercooling

\section{INTRODUCTION}

"Insect cold hardiness: to freeze or not to freeze" (Lee 1989), "Insect cold hardiness: a matter of life and death" (Bale 1996) and "Life on the edge: insect ecology in arctic environments" (Strathdee \& Bale 1998), are some of the most effective titles to highlight the difficulty of withstanding the rigors of winter in habitats that freeze, at high latitudes and altitudes. The ability of insects to face winter in a frozen state was first investigated in the 1930s, and has since been well documented for many taxa, mainly terrestrial, and by many researchers, mostly from North America (e.g., Downes 1965; Block 1980; Andrews \& Rigler 1985; Lee \& Denlinger 1991; Moore \& Lee 1991; Irons et al. 1993; Danks 2000a).

The interest of ecologists, zoologists, physiologists and biochemists in understanding the strategies adopted by insects to survive in cold environments has many reasons. Firstly, it was supposed that the evolution of most aquatic insects (e.g., Chironomidae, Empididae and Plecoptera) started in cold and running headwaters several hundred million years ago and the conquest of all the other habitats was secondary (Danks 1971a;
Danks \& Oliver 1972a). Their physiological adaptations may have been forged in their early evolutionary history and biogeographic patterns in taxonomic diversity (i.e. latitudinal and altitudinal gradients) could thus be related to the ability to survive subzero temperatures (Oswood et al. 1991; Rossaro 1991). Secondly, winter mortality is a major factor determining population dynamics of aquatic and terrestrial insects in polar and alpine regions (Oswood et al. 1991). Furthermore, investigation of the ecology and physiology of cold tolerance in insects has practical applications in understanding the overwinter survival of pest species in agriculture and forestry (Block 1990). Similarities were found between physiological and/or biochemical processes that determine resistance to cold, anoxia, desiccation and to chemical products as pesticides. These different resistance forms resulted to produce and accumulate the same or similar substances (i.e. the "stress" or "shock proteins"). Finally, the studies on insect cold hardiness find application in cryobiology (Block 1990).

This paper aims to synthetize existing information on cold adaptations in freshwater insects living at high latitude and altitude, with some recent findings for the Italian Alps. 


\section{ENVIRONMENTAL CONSTRAINTS AT HIGH LATITUDE AND ALTITUDE}

Regions at high altitude and latitude share similar "extreme" environmental conditions, characterised by a high degree of harshness due to a combination of severity, seasonality, unpredictability and variability (Mani 1962; Danks 1999a).

The limiting factors of these habitats are: extended period of snow/ice cover (from 6 to 10 months a year); short growing season (concentrated in the period free from ice/snow cover); reduced quantity and quality of food; high risk of drought; low precipitation; poor quality of the soil; strong winds and very low temperature with ample daily and seasonal excursions, especially in exposed terrestrial microhabitats, shallow ponds and small streams. In both terrestrial and water habitats, temperature is near the physiological minimum of insect life, and few species are able to adjust their metabolism to be active in these conditions and complete their life cycle. In the Arctic, air temperature may range from $-50 /-70{ }^{\circ} \mathrm{C}$ in winter to $+10 /+15{ }^{\circ} \mathrm{C}$ in summer, and that of temporary water bodies from $-20{ }^{\circ} \mathrm{C}$ in winter to +20 ${ }^{\circ} \mathrm{C}$ in summer (Downes 1964, 1965; Oliver 1968; Danks et al. 1994; Strathdee \& Bale 1998).

A decrease in species richness and diversity occurs with increasing latitude and altitude, due to growing environmental harshness and isolation condition, to which low rates of colonisation, speciation and generally high extinction rate are also associated (Mani 1968; Ward \& Stanford 1982; Downes 1988; Danks 1990; Stevens 1992; Ward 1994; Strathdee \& Bale 1998; Füreder 1999).

Freshwaters at high latitudes (Downes 1964, 1965) and altitudes (Brittain \& Milner 2001; Lods-Crozet et al. 2001a; Maiolini \& Lencioni 2001) are colonised mainly by Diptera Chironomidae for which adaptations to a variety of environmental rigors such as desiccation, anoxia, extremely high and low temperatures and freezing have been described (Danks 1971a). Chironomids are the most widely distributed insect family in freshwaters, comprising about 15,000 species, corresponding to $25 \%$ of aquatic insects (Cure 1985; Cranston 1995). Diptera Simuliidae, Tipulidae, Culicidae, Empididae and Limoniidae are also frequent in cold freshwaters, besides Plecoptera, Ephemeroptera and Trichoptera (Downes 1964, 1965; Ward 1994).

\section{ADVANTAGES AND DISADVANTAGES OF LIVING IN FRESHWATER THAT CAN FREEZE}

Aquatic insects generally face less extreme conditions than terrestrial ones. The main reason is that water acts as a thermal buffer (temperature variations are less sudden and ample than on land) (Danks 1971b) and current delays ice formation (Füreder 1999). Aquatic insects face thus more gradual seasonal changes and can exploit for longer periods the growing season than terrestrial ones (Danks \& Oliver 1972a). However, in some water bodies (e.g., shallow ponds and streams) and microhabitats (e.g., littoral zone of lakes and riverbanks), aquatic insects also can face desiccation (Kownacki 1985; Hayes \& Murray 1987), anoxia and freezing (Nagell \& Brittain 1977; Füreder 1999).

Ice may occur in several forms in freshwater systems (surface ice, frozen substrate, frazil ice, anchor ice), each with different influence on biota (Oswood et al. 1991). Surface snow/ice principally affects the chemistry of the underlying water, preventing gas exchanges and limiting light penetration, therefore hindering photosynthesis and favouring accumulation of carbon dioxide and depletion of oxygen. In these anoxic conditions, there can be also the production of toxic gases (i.e. $\mathrm{H}_{2} \mathrm{~S}$ ) that remain trapped under the ice cover and may cause death of fish and invertebrates (Oswood et al. 1991). Desiccation, anoxia and freezing remain dreadful threats to the adult stages of all aquatic insects. With the exception of Coleoptera and Hemiptera Heteroptera, adults are terrestrial and so must face the same survival problems as land insects (e.g., strong wind and rapid air temperature variations). Aquatic insects are therefore under two different selection pressures, one acting on the aquatic (immature) phase and one on the terrestrial (mature) one. It was demonstrated that this dichotomy tends to reduce or even eliminate one of the two phases that is generally the terrestrial one, represented by fragile adults, susceptible to desiccation and easily dispersed by wind (Downes 1962; Brittain 1990). This is particularly true in "extreme" environments (see 4.1. Morphological adaptations).

\section{COLD ADAPTATIONS OF FRESHWATER INSECTS}

Cold adapted insects have developed a complex of strategies that allow survival at their physiological temperature minimum. These strategies comprise (a) morphological, (b) behavioural, (c) ecological, (d) physiological and biochemical adaptations. Generally, most species develop a combination of these survival strategies (Irons et al. 1993).

\subsection{Morphological adaptations}

Morphological adaptations include: 1) melanism, 2) reduction in size, 3) hairiness/ pubescence, 4) brachyptery and aptery.

1) Melanism is diffused in terrestrial as in aquatic insects from cold environments and it has two main functions: protect from UV-B radiation injury and favour heat absorption (thermoregulatory function), for example by basking in the sun (Downes 1962, 1965).

2) Terrestrial and aquatic insects from polar and alpine regions generally exhibit smaller size than relative species at lower altitudes and latitudes (e.g., the size of Tipula arctica (Curtis) decreases of $4.5 \%$ for each increase of $10^{\circ}$ in latitude from southern to northern Greenland) (Downes 1962, 1965). This has several ad- 
vantages: a lower request of food in habitats where this is rather scarce; a faster growth and development, forming large populations with a high rate of increase, thus reducing the possibilities of extinction; a major possibility to find sheltered microhabitats for protection during winter.

3) On the contrary, some insects from polar regions develop big and hairy bodies in contrast to specimens from warmer environments. This was highlighted for some terrestrial taxa (e.g., bumble bees), with big size and hairiness or pubescence that allow them to maintain the heat generated by the contraction of the flight muscles (Downes 1965).

4) Flight covers several essential functions, from searching for food to searching for a suitable summer and winter habitat, escaping predators, dispersion of the species and finding mates (swarms are commonly monospecific and have the function of concentrating the two sexes in a restricted area, Oliver 1968). All these functions are suppressed, reduced or transferred on the ground in most insects from cold regions (Downes 1969).

The reduction or absence of wings (brachyptery and aptery respectively) can be a response to i) air temperature lower than the physiological threshold of flight ii) or to strong winds that make it difficult to maintain a specific direction of flight, hindering the formation of swarms or transferring insects to unfavourable habitats (Downes 1962, 1965). Brachyptery and aptery may interest both sexes, though more frequently only males are short-winged, while normal-winged females are able to function as a dispersal agent after mating (Downes 1962, 1965). Wing reduction has been observed in Diptera, Plecoptera and Coleoptera while others, such as Ephemeroptera, invariably mate in flight and this habit has limited their distribution in arctic and alpine regions (Brittain 1990). In some populations, brachyptery was observed also in females, probably to save resources for the growth or the maturation of eggs in environments where food is scarce. The construction of wings and of their musculature is in fact highly energy consuming, delaying maturation of individuals with the risk of not having enough time to complete the life cycle before winter (Brittain 1990).

Brachyptery and aptery is generally associated with changes in mating and/or feeding habits, involving a series of secondary morphological modifications. For example, brachypteran and apteran arctic Diptera have been observed mating on the ground rather than in swarms. In males this habit involves an enlargement and a major sclerotisation of genitalia, the enlargement of the femurs and the inactivation of sexual receptors used to recognise females in flight (antennae in Culicidae, Ceratopogonidae, Chironomidae and Chaoboridae; eyes in Simuliidae, Empididae and Thaumaleidae) (Downes 1969). Brachypterous males of High Arctic Chironomidae have been observed to copulate with any type of object on the ground. However, the risk to copulate with a female of a different species is very low, being very low the number of species emerging in a specific place and period (Downes 1969).

Feeding activity in some arctic aquatic insects such as Culicidae and Simuliidae is at least partially suppressed (Downes 1969). The adult females of these aquatic insects need a blood meal after emergence to gain energy and complete the maturation of eggs. In case of brachypteran or apteran populations, females forsake the blood meal and use the reserves stored by the larvae to complete the maturation of the eggs (autogeny). This increases the survival probabilities in an environment where the potential hosts are extremely rare. Such a change of feeding habit involves in turn other morphological adaptations, as modifications of the mouth apparatus (the sucking parts, used to pierce the skin of the host, are no more necessary). In strictly autogenic species, follicular development starts in the pupa and the maturation of the eggs is completed in the pharate adult. The adult female emerges with completely mature follicles and is ready to mate without feeding. Copulation may so occur on the water surface or on the ground close to the emergence point. This was observed also in chironomids from arctic streams (Downes 1969). In this way, there is no dispersion of the two sexes, the percentage of copulation is high and the risk of predation low. The main disadvantage is that the dispersion of the species is extremely limited and mating between individuals from the same hatch might be frequent.

To reduce completely the risk of dispersion of the two sexes, that could represent a total failure in reproduction in extremely windy areas, some aquatic insects adopt parthenogenetic reproduction. The presence of parthenogenetic male-less populations has been observed in Diptera, Ephemeroptera and Plecoptera from northern regions (Downes 1964; Brittain 1990). Females of High Arctic Prosimulium ursinum Edwards do not emerge, the maturation of parthenogenetic eggs occurs in the pharate adult and during the ecdysis the eggs are left directly in the water. These females produce a lower number of eggs but bigger than those produced with sexual reproduction by the same species at lower latitudes, so to ensure more nourishment to the larvula (Downes 1962, 1965).

Parthenogenesis has been found associated with polyploidy in several aquatic insects from North America (Downes 1965). Polyploidy ensures stability to a specific phenotype and this is advantageous in an unpredictable environment, to avoid the loss of a particular genotype and phenotype in response to a temporary condition. Responses to sudden changes could in fact eliminate precious genotypes and phenotypes only temporarily disadvantageous (Downes 1962, 1965). Ovoviviparity was also observed in some Plecoptera (Capniidae) and Ephemeroptera (Baetidae) from Norwegian streams (Brittain 1990). 


\subsection{Behavioural adaptations}

Behavioural adaptations include: 1) basking in the sun, 2) feeding and mating habit, 3) parthenogenesis, polyploidy and ovoviviparity, 4) habitat selection, and 5) cocoon building. Points 1,2 and 3 were discussed within the morphological adaptations.

4) Most larvae of freshwater insects avoid freezing or desiccation by being located in a portion of the water body that will not freeze or by moving from the freezing or drying front (Olsson 1981; Irons et al. 1983; Kownacki 1985). In lakes, insects refuge in the central part of the water body, near or in the bottom. In streams, the majority of invertebrates avoid the hazards of freezing by migrating to unfrozen habitats (e.g., areas of groundwater inputs and hyporheic zone), where they remain active (Irons et al. 1983; Oswood et al. 1991). These refugia may provide colonizers for nearby areas in which the fauna can be substantially reduced as a result of winter mortality. The hyporheic zone represents a refuge from a variety of environmental disturbances such as warm temperatures or floods in summer and freezing in winter (Stanford \& Ward 1988, 1993; Irons et al. 1993; Füreder 1999; Malard et al. 2002). In Alaskan streams, it was highlighted that reaches fed by groundwater do not freeze into the substrate and support much higher densities of macroinvertebrates than nearby streams and rivers that completely freeze. This suggests that aquatic macroinvertebrates may be limited by the availability of non-freezing sites for overwintering (Irons et al. 1993). In early spring, egg masses of some Diamesa species (Diptera: Chironomidae: Diamesinae) (Fig. 1) were found by the Author in a "refuge area" (a small springbrook) near an Alpine glacial stream partially frozen and completely covered by snow (Noce Bianco, Italy, $46^{\circ} \mathrm{N}, 2400 \mathrm{~m}$ a.s.1.). In summer, the same species were found abundant in the nearby glacial stream. However, reaches of glacial streams that do not freeze in winter, can host zoobenthic communities richer in species and individuals than the same reaches in summer. This was highlighted for some Swiss (Ward et al. 1999; Klein \& Tockner 2001) and Italian (Lencioni \& Maiolini 2002) glacial streams and for high mountain streams in the High Tatra Mountains (Krno et al. 2000). In the slow, shallow, transparent and cold winter waters, algae and invertebrate may find more favourable conditions than in summer, when discharge and turbidity are high and widely variable during the day (up to 5-10 higher in the afternoon than in the morning) and the substrate is very unstable (Castella et al. 2001; Robinson et al. 2001). If in summer almost exclusively Diamesinae populate the kryal biotopes, in winter Plecoptera, Ephemeroptera and Trichoptera can be the major colonisers (Lencioni \& Maiolini 2002). Mating Pseudopsilopteryx zimmeri McLachlan (Trichoptera) were found on the snow covered bank of the Noce Bianco glacial stream (Trentino, Italy) in winter (Fig. 2a, b). This species was completely absent in this stream in summer. In such cases, unfrozen glacial streams represent "winter refuge areas" for typical krenal/rhithral taxa when their "summer habitat" is dried or frozen.

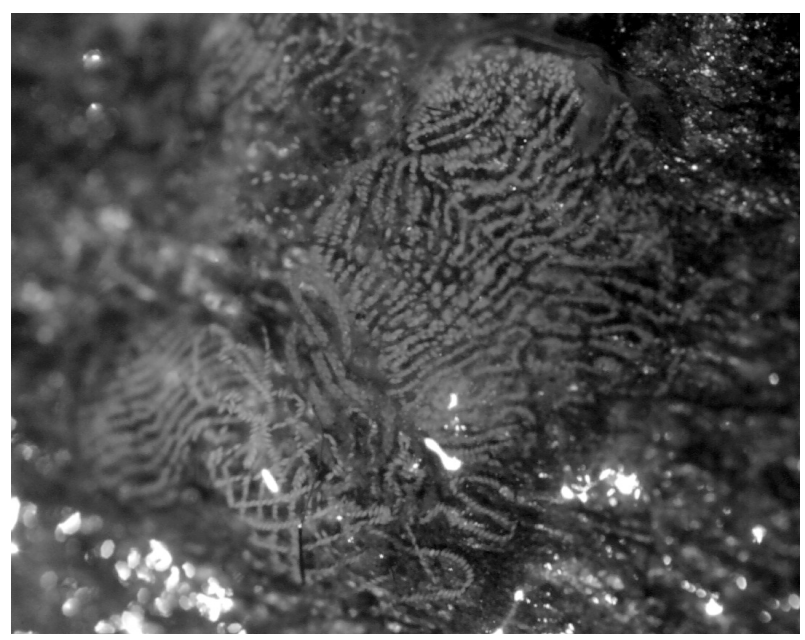

Fig. 1. Early spring eggs of Diamesa and Pseudodiamesa (Diptera: Chironomidae: Diamesinae) in a high altitude springbrook (Italian Alps, $46^{\circ} \mathrm{N}, 2400 \mathrm{~m}$ a.s.1.) (Photo by V. Lencioni).

Winter/early spring emergence and mating beneath snow/ice cover or through cracks formed in the ice/snow pack were also observed (Oliver 1968; Danks 1999a). Hågvar \& Østbye (1973) recorded, from December to April in a Norwegian stream, chironomid adults of Diamesa permacra (Walker), Diamesa bohemani Goetghebuer, Pseudodiamesa branickii (Nowicki) and Chaetocladius laminatus Brundin, walking and copulating at subzero $\left(-1 /-2{ }^{\circ} \mathrm{C}\right)$ temperatures on the snow cover, and flying in the warmest days. In arctic lakes and streams, adults of Chironomidae (Pseudodiamesa artica (Malloch), Heterotrissocladius subpilosus (Kieffer) and Cricotopus alpicola Zetterstedt) and of Simuliidae (Prosimulium fucum Syme and Davies and of P. mixtum Syme and Davies), were observed emerging successfully through cracks in the ice cover at the beginning of thawing (Downes 1962, 1965; Oliver 1968; Danks \& Oliver 1972a). In these cases, larval growth continues slowly during winter beneath the snow/ice pack. Other taxa (e.g., two arctic mosquitoes) lay eggs along the south facing shore of lakes that melts faster and earlier in spring. This allows them to have fast development and to complete their life cycle within one year (Downes 1962). Finally, in some arctic streams, Empididae and Chironomidae were observed to remain, or even actively migrate, to habitats that will freeze at the onset of winter (Oswood et al. 1991). Dragonsflies and damselflies (Odonata) were also recorded in North American pools surviving encased in ice or in frozen sediments as many non-insect taxa (oligochaetes, leeches, ostracods, cladocerans, molluscs and water mites) (Irons et al. 1993). 

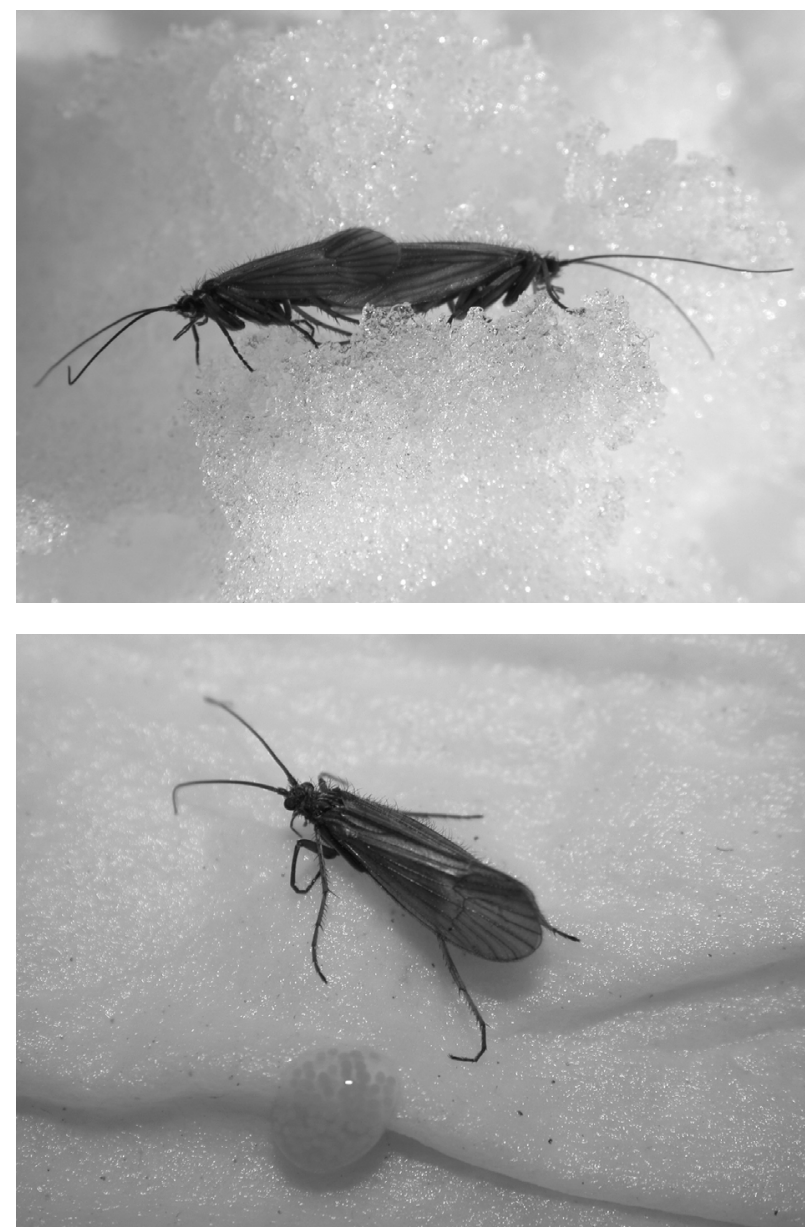

Fig. 2. Upper: mating Pseudopsilopteryx zimmeri (Trichoptera), close to the bank of an Alpine glacial stream in winter (Noce Bianco, Italy, $46^{\circ} \mathrm{N}$ ). Lower: P. zymmeri eggs deposed in the laboratory at $3{ }^{\circ} \mathrm{C}$ (Photo by B. Maiolini)

5) In winter, some aquatic insects (e.g., many chironomids) build smooth, transparent and thin cocoons using their saliva and suspend growth, development, movement and feeding (Danks 1971a). These cocoons are closed at both ends, enclose the animal tightly (no liquid is between the animal and the cocoon wall), maintain inner humidity and temperature higher than outside and hinder the inoculation of freezing when the insect is encased in ice (Frisbie \& Lee 1997). Before building cocoons, larvae of chironomids evacuate the gut and lay inside folded in two or three, always with posterior pseudopods bent towards the head capsule (Danks 1971a, 1996, 2000b). Different types of protective structures have been observed in other aquatic macroinvertebrates, as epiphragms (thin closure of shell mouth in snails), transparent cysts (oligochaetes) and closures across opening of caddiesfly cases (Oswood et al. 1991).

Several aquatic insects (e.g., many chironomids) build cocoons also in summer by packing mineral particles with saliva. These cocoons protect them from temperature excursions, current and from mineral particles flowing in the water column. Summer cocoons are larger than the animals and closed at one end, so that the insect can move inside and go out to feed (Danks 1971a).

\subsection{Ecological adaptations}

Natural environments impose integrated responses to many rather than single constraints on development of organisms (Gullan \& Cranston 1994; Danks 2000a).

The severity, seasonality, unpredictability and variability of the environmental conditions, along with the genetic potential of the insects and their ability to monitor the environmental changes, govern the life cycle patterns in polar and alpine regions (Oliver 1968; Strathdee \& Bale 1998; Danks 2000c). A wide range of life cycle types have been described for insects from these areas, with different duration, different number of generations per year and presence or absence of quiescence and/or diapause phases. In most cases, flexible and programmed elements are both present in the life cycle. The contrary could be disadvantageous in variable and unpredictable environmental conditions (Danks 1999a).

The most frequent adaptations in life cycles of insects from high latitudes or altitudes are 1) the extension of the development to several years by quiescence or diapause and 2) the reduction of the number of generations per year (Danks 1999a).

1) Quiescence and dormancy (or diapause) represent a temporary suspension of morphological development associated with a strong reduction of the metabolic rate to overcome adverse conditions. Diapause enhances survival also by ensuring that development or reproduction will coincide with favourable conditions (Hanski 1988; Danks 2001). In cold environments, species enter winter dormancy in a cold-hardy state, others prolong their development to prevent the appearance of coldsusceptible stages (Danks 2001). Temperature, photoperiod and food availability have been reported as factors that more influence the start and end of diapause, which is also under hormonal control (Gullan \& Cranston 1994).

Two types of diapause are described: facultative (as direct response to unfavourable environmental conditions and, when started, must last a certain period) and obligatory (it occurs every year to avoid a specific period, independently from environmental changes to unfavourable conditions that, however, it could be adapted to avoid). Obligatory diapause in aquatic insects is more frequent in eggs and larvae, less in the pupa or pharate adult, almost never in the adult (Danks 1996). Evidence of diapausal eggs was recorded for Diamesa latitarsis (Goetghebuer), living in a temporary stream in the High Tatra Mountains (Kownacki 1985), for Baëtis macani Kimmins and for some Plecoptera Systellognatha from Norwegian mountain streams (Brittain 1975; Lillehammer 1987). 
The programmed diapause ensures a synchronised emergence of individuals of the same species. Synchronisation due to programmed diapause controlled by temperature may not be perfect among ponds in the same area, with different exposure and shelter. In this way, insects may exploit the entire short growing season and reproduce in the most favourable period (Danks \& Oliver 1972a).

Repeated or prolonged diapause in response to environmental adversities (e.g., as cold or unpredictable temperatures, patchy, unreliable or low quality food supplies and natural enemies, is one of the main reasons for long life cycles in High Arctic (Danks 1992, 1999a, 1999b). Modest extensions, such as development over 2-years, prolonged dormancy for one additional adverse season, "cohort splitting" between 1- and 2-year life cycles and oviposition over two seasons, are relatively common. On the contrary, extreme extensions of the life cycle, such as diapause for more than 10 years, usually affect only a very small fraction of a population. The phenomenon of "cohort splitting" was observed in some aquatic insects (Chironomidae and Culicidae) from arctic ponds (Danks 1999a). In these cases, different larvae belonging to cohorts with the same age, but inhabiting different microhabitats, complete their development at different periods of the year and even in different years (Danks 1992). The same phenomenon was observed in some Plecoptera that have genetically programmed eggs for direct hatching and facultative or obligatory diapause in the same hatch (Zwick 1981, 1999; Økland 1991). Prolonged diapause has been observed in several aquatic insects (e.g., 3-year dormancy pupae and prepupae of Anthomyidae from the Arctic, Danks 1992).

Typically, the life cycles of aquatic insects from polar and alpine habitats are characterised by a high flexibility, including opportunism in the immature stages and programming in the adult phase. The duration of the larval phase is not fixed and growth and development occur within a relatively wide temperature range. Pupation and emergence can occur only at a specific temperature value and only in a fixed period of the year (Danks 1971b). This is the case of the "spring species", described for the first time within chironomids from arctic ponds (Chironomini such as Chironomus and Glyptotendipes) (Danks 1971b; Danks \& Oliver 1972a; Hodkinson et al. 1996). In these species, emergence may occur only in spring by larvae that overwintered in a diapausal status as pre-pupae ( $4^{\text {th }}$ larval instar) ready to transform in pupa without further feeding. All the other instars continue their development during summer, enter diapause when they reach the $4^{\text {th }}$ instar, and will emerge the next year in spring, so extending diapause (Danks 1971b). In the "spring species", obligatory diapause at the $4^{\text {th }}$ instar can be interrupted only by a suitable temperature but emergence requires higher temperatures $\left(4-5{ }^{\circ} \mathrm{C}\right.$ and $7-8{ }^{\circ} \mathrm{C}$ respectively in the High Arctic) (Danks \& Oliver 1972a). If these thermal thresholds are not reached in spring or early summer, emergence will be postponed to the next year. Emergence process is also under the control of day-length. This double control hinders emergence in late summer in case of prolonged winter and reaching of the threshold temperatures for pupation and emergence in late summer. In many aquatic Diptera it was observed that there is an increasing series of threshold temperatures for successive stages, so temperature stimulating the growth of the $1^{\text {st }}$ instar is lower than that stimulating the growth of the $2^{\text {nd }}$ one and so on (Oliver 1968). This mechanism seems to be at the basis of the synchronised emergence in individuals belonging to the same species and living in the same area. Emergence typically peaks near midday in spring species (e.g., in arctic chironomids) and at dusk in summer species (e.g., in temperate chironomids) to avoid, in the first case, the chilly evening air temperature and, in the second case, the risk of desiccation and predation (Oliver 1968; Danks \& Oliver 1972a, b). It appears that the group of chironomids that have been able to adapt to the spring conditions in the temperate regions have also successfully invaded the arctic regions (Oliver 1968).

Extra long diapause may be achieved by completing it exceptionally late (prolonged diapause), or by entering it exceptionally early (premature diapause), as response to the year-to-year variability in the length of the adverse season and to the suitability of the breeding season (Hanski 1988).

Long life cycles in insects can be associated also with very slow but continuous growth and/or long-lived adults (Danks 1992). Slow but continuous growth has been observed for several Alaskan and Canadian chironomids, such as Chironomus hyperboreus (Linneus) (2-year life cycle), Chironomus prior Butler, C. tardus Butler (7-year life cycle), Diamesa davisi Edwards (1-2 year life cycle) and for the trichopteran Dicosmoecus atripes (Hagen) (2-year life cycle) (Sæther 1968; Butler 1982). Long-lived adults have been observed more frequently in terrestrial species, characterised more than aquatic insects by repeated breeding (iteroparity) (Block 1980).

2) The reduction of the number of generations per year has been reported for several arctic (Danks 1999a) and alpine (Lencioni 2000; Snook \& Milner 2001) aquatic insects. Uni- or bivoltinism is considered strategic when the favourable season for breeding is very short (Hanski 1988). Experimental growth chambers used at $2200 \mathrm{~m}$ a.s.l. in the Taillon stream (Switzerland), demonstrated that egg hatching to pupation of Diamesa zernyi Edwards takes, at an average water temperature of $4.5^{\circ} \mathrm{C}$, between 39-54 days in June-July (Snook \& Milner 2001). Analysis of larval head capsule widths suggested that several species (e.g., Diamesa bertrami Edwards, Diamesa latitarsis (Goetghebuer) and Diamesa steinboecki Goetghebuer) from Alpine glacial streams are bivoltine, with emergence periods in 
June/July and August/September (Lencioni 2000; Snook 2000). Nemurella pictetii Klapálek and Nemoura cinerea (Retzius) (Plecoptera) were reported as semivoltine from mountain streams in southern Norway (Brittain 1974, 1978, 1983).

Opportunistic species with $r$-strategy are diffused and generally these species are multivoltine without a defined number of generations and a defined length of their life cycle. Larvae of Procladius have been observed in a pond at Hazen Camp (northern Ellesmere Island, $81^{\circ} \mathrm{N}$ ) to grow as conditions permit and do not have a definite length to the life cycle (Oliver 1968). These species exploit every favourable condition and respond rapidly to environmental changes. $K$-strategy is also diffused in species occupying rather stable habitats or characterised by a predictable variability. These species have generally a high resistance to environmental changes, longevity and slower development (Danks 1999a).

\subsection{Physiological and biochemical adaptations}

The capacity to survive prolonged exposure to subzero temperature without undergoing injury is ensured by "cold hardiness", as 1) freezing tolerance (hibernation) and/or 2) freezing avoidance (supercooling) (Salt 1961; Bale 1987, 1993; Danks 2000a). Insects without this capacity, if exposed even for a short time to subzero temperature, firstly enter in a stupor or torpor status (animal ceases to feed and limits movements), then in coma (animal ceases every activity and maintains a low rate of metabolism) and finally die due to freezing processes (Bale 1996). Cold hardiness is necessary in winter but at high latitudes, where the growing season lasts only few weeks, it is required also in summer (Block 1990). In aquatic insects, supercooling is more frequent than hibernation, while the contrary was observed for terrestrial ones, being the water a thermal buffer for temperature variations. However, there is some evidence of cold hardiness in aquatic insects, mainly in chironomids (Danks 1996).

1) Hibernation involves the freezing of the extracellular fluids and, only very rarely, the complete freezing of tissues. The freezing of the haemolymph starts slowly at relatively high subzero temperature (from -5 to -10 ${ }^{\circ} \mathrm{C}$ ) allowing the control of the ice crystal formation by the insect (Block 1990; Bale 1996).

Ice crystal formation is promoted by specific substances called Ice Nucleators or Ice Nucleating Agents (INAs), that can have an internal or external origin. Internal nucleators are generally proteins or lipoproteins that are synthesised by the insects for this aim and deposited in the haemolymph (Strathdee \& Bale 1998). External nucleators can be the organic matter present in the gut (food particles) or mineral soil particles, dust and microorganisms as bacteria inoculated through the cuticle. The growth of ice crystals starts around these nuclei, involving all molecules of non-bound water, which are encouraged to assume the hexagonal configuration of the ice crystals (Block 1990; Danks 1996).

The temperature at which ice formation and the growth of ice crystals start, is defined and controlled by specific substances synthesised for these aims by the insect, the cryoprotectans and anti-freezers. Two types of crioprotectants and antifreezers are known: those with low molecular weight and those with high molecular weight (Storey 1990). The first ones are represented by polyols (polyhydroxy alcohols e.g., glycerol, mannitol and sorbitol), sugars (e.g., glucose, fructose and tethralose) and amino-acids (e.g., alanine). These substances act in a colligative manner and are highly soluble in aqueous solutions (water-binding molecules) (Duman et al. 1982). The second ones are the Thermal Hysteris Proteins (THPs), proteins similar to those synthesised by fish overwintering at very low temperatures in deep polar waters (Feeney \& Burcham 1986; Clarke 1991). THPs are present also in the cellular matrix (Danks 1996).

On the whole, all these substances have the role to: depress of some degrees the freezing point of body fluids (= supercooling point, $\mathrm{SCP}$ ) that in most insects is around $-10{ }^{\circ} \mathrm{C}$ (Bale 1996), protect macromolecular structures from freezing injuries, stabilise proteins and enzymes against cold denaturation, limit the growth of ice crystals, avoid the recristalisation of ice during winter freeze-thaw cycles or during the spring thawing. Furthermore, they represent a reserve of aminoacids, carbon and water easily available in spring, when thawing occurs (Duman et al. 1982).

Freezing tolerant insects spend winter in a partially dehydrated state (Danks 1971a). The substances with low molecular weight, when accumulated in the haemolymph, increase the osmotic pressure of the extracellular fluids drawing water from the intracellular matrix, reducing the risk of freezing for the cellular matrix (Danks 1971a, 2000b). Once in the haemolymph, it may be used for ice crystal formation, bounded by cryoprotectants and antifreezers or, if the insect remains encased in a frozen substrate, eliminated through the cuticle. It was observed that midges from temporary streams and ponds in polar regions, are able to tolerate a water loss of more than $90 \%$ of their body content without injury, facing temperatures of $-20{ }^{\circ} \mathrm{C}$ for several months (Oswood et al. 1991). Visibly wrinkled $4^{\text {th }}$ instar larvae of Diamesa zernyi were collected in late autumn 2003 in a frozen reach of the Noce Bianco glacial stream (Trentino, NE-Italy, $46^{\circ} \mathrm{N}$ ) (Fig. 3a); they completely recovered in the laboratory after 45 minutes in water at $4{ }^{\circ} \mathrm{C}$ (Fig. 3b). In spring re-hydration occurs very fast, mainly through the release of bound water by cryoprotectants as they are catabolised but also, in diapausing insects, by the metabolism of lipids. Some water could be taken from the environment (Block 1990).

Furthermore, insects encased in ice for several months, must face low oxygen levels, due to reduced 
gas exchanges through ice that requires an anaerobic respiration (Nagell \& Brittain 1977). Several Authors suggested that surviving cold requires also the capacity to survive low levels of oxygen and desiccation and that the capacity to tolerate low relative humidity is a preadaptation to cold tolerance (Sømme 1986). Evidences of anoxia resistance at low temperature are for nymphs of the mayfly Leptophlebia vespertina (Linnaeus) from South Norwegian ponds (Brittain \& Nagell 1981).
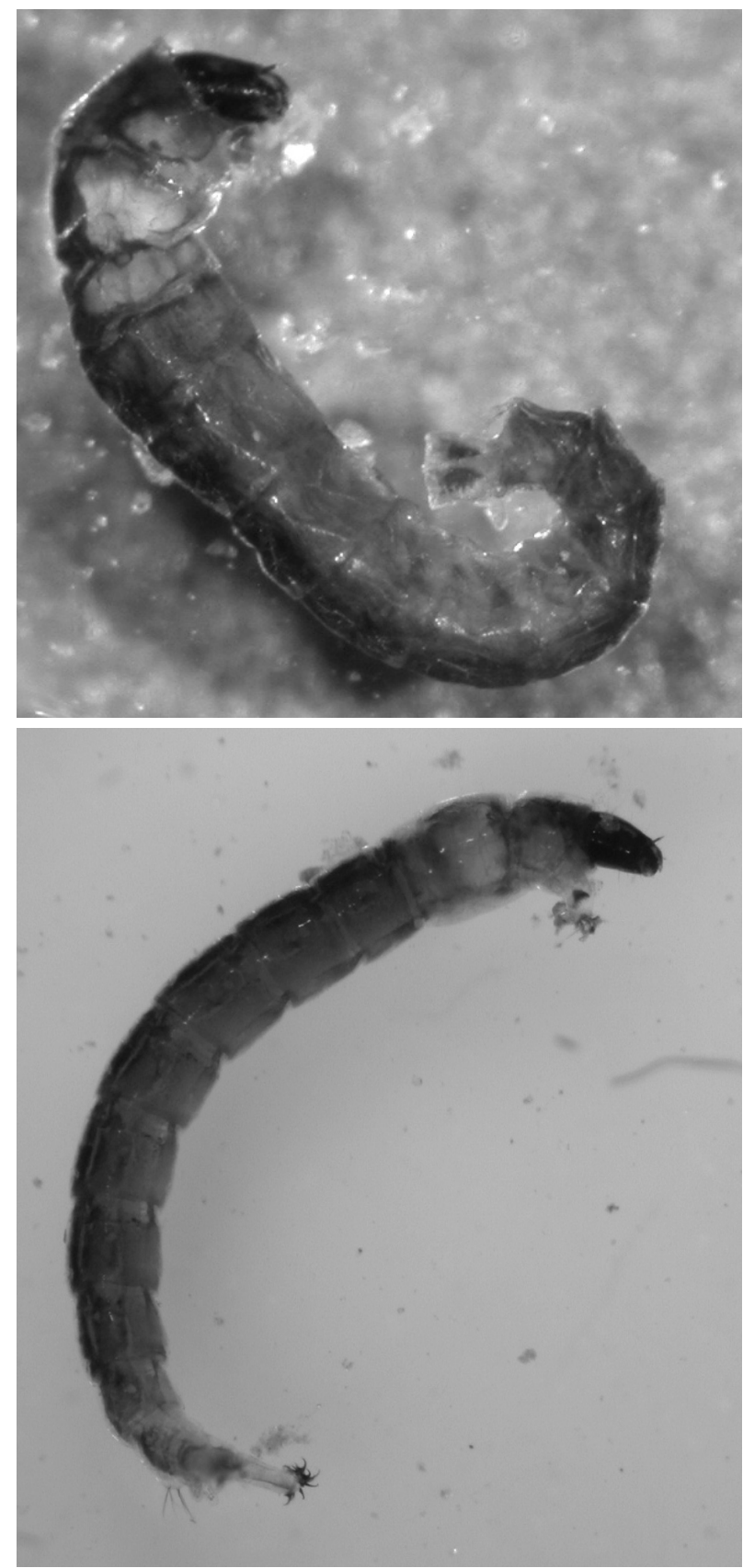

Fig. 3. Upper: visibly wrinkled $4^{\text {th }}$ instar larva of Diamesa zernyi (Diptera: Chironomidae: Diamesinae) overwintering in a frozen reach of the Noce Bianco glacial stream (Italian Alps, $46^{\circ} \mathrm{N}, 2450 \mathrm{~m}$ a.s.1.). Lower: the same larva completely recovered after 45 minutes in water at $4{ }^{\circ} \mathrm{C}$ (Photo by V. Lencioni).
The main factors influencing survival in a frozen state are the minimum exposure temperature and the duration of the exposure to extremely low temperatures and repeated freeze-thaw cycles. Generally, once frozen, insects in this state can survive exposure to $-40 /-80{ }^{\circ} \mathrm{C}$ for a short period or to $-20 /-40{ }^{\circ} \mathrm{C}$ for many months (Danks 1996).

Hibernation was observed for empidids, chironomids (mainly Diamesinae and Orthocladiinae), Dragonflies and many non-insect taxa (oligochaetes, leeches, ostracods, cladocerans, molluscs and water mites) (Oliver 1968, 1971; Danks 1971a; Steffan 1971; Irons et al. 1993).

2) Supercooling is given by the maintenance of body fluids in a non-frozen state at temperatures much lower than the natural freezing point (SCP) to $-20 /-40$ ${ }^{\circ} \mathrm{C}$ (Bale 1996; Strathdee \& Bale, 1998). To lower the natural SCP, at the beginning of winter, larvae eliminate the gut content that could act as ice nucleators, and synthesise big amounts of cryoprotectants and antifreezers in the haemolymph, mainly at low molecular weight. These substances can reach very high concentrations, around $0.4-0.6 \mathrm{M}$ to $4-5 \mathrm{M}$ (= from 3-6\% to 10 $14 \%$ of fresh weight percentage) (Ring 1982). In some cases, a vitrification process occurs, due to the high concentration reached in the body fluids of glycerol at 20/-30 ${ }^{\circ} \mathrm{C}$ : ice crystals are absent and the haemolymph is in a glassy, vitrified state (non-crystalline) (Danks 1996). Supercooling was observed frequently in larvae of aquatic insects, and in some cases also in adults. It is the case of adults of a Himalayan species of Diamesa found active at $-16{ }^{\circ} \mathrm{C}$ near a glacier; these adults went into heat shock after 20 seconds when held in the hand (Kohshima 1984).

In both freezing tolerant and intolerant insects, reserves as lipid and glycogen are accumulated during summer and transformed in cryoprotectants and antifreezers in late autumn/early winter. This preparation to overwinter consists in an acclimation process stimulated by a decrease in temperature but also by a shorter day length, scarcity of food quantity or quality, increase in parasites, etc. Glycogen phosphorilase, the enzyme involved in the metabolism of glycogen, seems to be stimulated by cold. The synthesis of polyols in particular, requires the suppression of the oxidative metabolism of carbohydrates with the transformation of glycogen in glycerol, mannitol and other alcohols (Bale 1996; Strathdee \& Bale 1998).

Freezing avoidance and freezing tolerance may be accompanied by diapause (Irons et al. 1993; Danks et al. 1994). Both cold hardiness and diapause manifest during the unfavourable season and: (i) involve storage of food resources (e.g., glycogen and lipids before entering diapause), (ii) are under hormonal control (ecdysone and juvenile hormone), (iii) involve a depression or suppression of the oxidative metabolism with mitochondrial degradation (Danks et al. 1994; Danks 1996). 
However, at least at high latitudes, where the growing season is reduced to a few weeks, insects may develop cold hardiness without entering diapause, maintaining THPs in the haemolymph in high concentration for the entire year and slow but continuous growth (Danks et al. 1994).

\section{FINAL REMARKS}

Survival strategies of insects living in "extreme" environments, such as the polar regions, have attracted many zoologists, especially from North America. From the reviewed literature, it has been highlighted that many morphological, behavioural, ecological, physiological and biochemical adaptations are common in land and aquatic insects, e.g. basking in the sun, brachyptery, long life cycles, diapause, supercooling and hibernation. However, data on aquatic insects are still scarce respect to those available on terrestrial ones.

In the last decade several ecological studies have been carried out on Alpine aquatic ecosystems in Italy (e.g., Boggero et al. 1996; Lencioni et al. 2001), Switzerland (e.g., Lods-Crozet et al. 2001b) and Austria (e.g., Füreder et al. 2001), but investigations on this topic are still few, especially from a physiological and biochemical point of view.

\section{ACKNOWLEDGMENTS}

A special thank to O. Ravera who encouraged the publication of this work and for his helpful comments on the manuscript. I am very grateful to J.E. Brittain, H.V. Danks and M.W. Oswood for providing many interesting references. Data referred to the Noce Bianco stream system were produced within the HIGHEST (Health and Integrity of Glacial Headwater EcosyStems in Trentino, 2001-2004) and the VETTA (Valenza ecologica dello zoobenthos di torrenti alpini, 20032006) projects, both funded by the Autonomous Province of Trento (Italy).

\section{REFERENCES}

Andrews, D. \& F.H. Rigler. 1985. The effects of an Arctic winter on benthic invertebrates in the littoral zone of Char Lake, North-west Territories. Can. J. Zool., 63: 28252834.

Bale, J.S. 1987. Insect cold hardiness: freezing and supercooling - an ecophysiological perspective. J. Insect Physiol., 33(12): 899-908.

Bale, J.S. 1993. Classes of insect cold hardiness. Funct. Ecol. 7: 751-753

Bale, J.S. 1996. Insect cold hardiness: a matter of life and death. Eur. J. Entomol., 93: 369-382.

Block, W. 1980. Survival strategies in polar terrestrial arthropods. Biol. J. Linn. Soc., 14: 29-38.

Block, W. 1990. Cold tolerance of insects and other arthropods. Phil. Trans. R. Soc. Lond., B 326: 613-633.

Boggero A., A.M. Nocentini, M. Nobili \& M. Gianatti. 1996. Ricerche sulla fauna macrobentonica litorale in laghi d'alta quota nel bacino imbrifero del Lago Maggiore. Atti S.It.E., 17: 83-86.
Brittain, J.E. 1974. Studies on the lentic Ephemeroptera and Plecoptera of southern Norway. Norsk. Entomol. Tidsskr., 21: 135-154.

Brittain, J.E. 1975. The life cycle of Baëtis macani Kimmins (Ephemerida) in a Norwegian Mountain Biotope. Entomol. scand., 6: 47-51.

Brittain, J.E. 1978. Semivoltinism in mountain populations of Nemurella pictetii (Plecoptera). Oikos, 30: 1-6.

Brittain, J.E. 1983. The influence of temperature on nymphal growth rates in mountain stoneflies (Plecoptera). Ecology, 64(3): 440-446.

Brittain, J.E. 1990. Life history strategies in Ephemeroptera and Plecoptera. In: Campbell, I.C. (Ed.). Mayflies and Stoneflies. Kluwer Academic Publishers: 1-12.

Brittain, J.E. \& A.M. Milner. 2001. Ecology of glacier-fed rivers: current status and concepts. Freshwat. Biol., 46(12): 1571-1578.

Brittain, J.E. \& B. Nagell. 1981. Overwintering at low oxygen concentrations in the mayfly Leptophlebia vespertina. Oikos, 36: 45-50.

Butler, M.G. 1982. Production dynamics of some arctic Chironomus larvae. Limnol. Oceanogr., 27(4): 728-736.

Castella, E., H. Adalsteinsson, J.E. Brittain, G.M. Gislason, A. Lehmann, V. Lencioni, B. Lods-Crozet, B. Maiolini, A.M. Milner, S.J. Saltveit, D.L. Snook. 2001. Modelling macrobenthic invertebrate richness and composition along a latitudinal gradient of European glacial streams. Freshwat. Biol., 46: 1811-1831.

Clarke, A. 1991. What is cold adaptation and how should we measure it? Am. Zool., 31: 81-92.

Cranston, P.S. 1995. Introduction. In: Armitage, P., P.S. Cranston \& L.C.V. Pinder (Eds). The Chironomidae. The biology and ecology of non-biting midges. Chapmann \& Hall, London: 1-7.

Cure, V. 1985. Chironomidae (Diptera-Nematocera) aus Rumanien unter besonderer Beruecksichtigung jener aus dem hydrographischen Einzugsgebiet der Donau. Arch. Hydrobiol. Suppl., 68: 163-217.

Danks, H.V. 1971a. Overwintering of some north temperate and arctic Chironomidae. II. Chironomid biology. Canad. Ent., 103: 1875-1910.

Danks, H.V. 1971b. Overwintering of some north temperate and arctic Chironomidae. I. The winter environment. Canad. Ent., 103: 589-604.

Danks, H.V. 1990. Arctic insects: instructive diversity. In: Harington C.R. (Ed.). Canada's missing dimension: Science and history in the Canadian arctic islands. Canadian Museum of Nature, vol. II: 444-470.

Danks, H.V. 1992. Long life cycles in insects. Canad. Ent., 124: $167-187$.

Danks, H.V. 1996. The wider integration of studies on insect cold-hardiness. Eur. J. Entomol., 93: 383-403.

Danks, H.V. 1999a. Life cycles in polar arthropods - flexible or programmed? Eur. J. Entomol., 96: 83-102.

Danks, H.V. 1999b. The diversity and evolution of insect life cycles. J. Entomol. Sci., 2(4): 651-660.

Danks, H.V. 2000a. Insect cold hardiness: a Canadian perspective. CryoLetters, 21: 297-308.

Danks, H.V. 2000b. Dehydration in dormant insects. J. Insect Physiol., 46: 837-852.

Danks, H.V. 2000c. Measuring and reporting life-cycle duration in insects and arachnids. Eur. J. Entomol., 97: 285303.

Danks, H.V. 2001. The nature of dormancy responses in insects. Acta Soc. Zool. Bohem., 65: 169-179.

Danks, H.V. \& D.R. Oliver. 1972a. Seasonal emergence of some high arctic Chironomidae (Diptera). Canad. Ent., 104: 661-686.

Danks, H.V. \& D.R. Oliver.1972b. Diel periodicities of emergence of some high arctic Chironomidae (Dipetra). Canad. Ent., 104: 903-916. 
Danks, H.V., O. Kukal \& R.A. Ring. 1994. Insect cold-hardiness: insights from the Arctic. Arctic, 47(4): 391-404.

Downes, J.A. 1962. What is an arctic insect? Canad. Ent., 94: 143-162.

Downes, J.A. 1964. Arctic insects and their environment. Canad. Ent. 96: 279-307.

Downes, J.A. 1965. Adaptations of insects in the Arctic. Ann. Rev. Entomol., 10: 257-274.

Downes, J.A. 1969. The swarming and mating flight of Diptera. Ann. Rev. Entomol., 14: 271-298.

Downes, J.A. 1988. The post-glacial colonization of the North Atlantic Islands. Mem. Entomol. Soc. Can., 144: 55-92.

Duman, J.G., K.L. Horwarth, A. Tomchaney, J.L. Patterson. 1982. Antifreeze agents of terrestrial arthropods. Comp. Biochem. Physiol., 73A(4): 545-555.

Feeney, R.E. \& T.S. Burcham. 1986. Antifreeze glycoproteins from polar fish blood. Ann. Rev. Biophys. Chem., 15: 59-78.

Frisbie, M.P. \& R.E. Lee Jr. 1997. Inoculative freezing and the problem of winter survival for freshwater macroinvertebrates. J. N. Am. Benthol. Soc., 16(3): 635-650.

Füreder, L. 1999. High alpine streams: cold habitats for insect larvae. In: Margesin, R. \& F. Schinner (Eds). Cold adapted organisms. Ecology, Physiology, Enzymology and molecular Biology. Springer-Verlag, Berlin: 181-196.

Füreder, L., C. Schütz, M. Wallinger \& R. Burger. 2001. Physico-chemistry and aquatic insects of a glacier-fed and a spring-fed alpine stream. Freshwat. Biol., 46(12): 16731690.

Gullan, P.J. \& P.S. Cranston. 1994. The insects - An outline of Entomology. Chapman \& Hall, London: $491 \mathrm{pp}$

Hågvar, S. \& E. Østbye. 1973. Notes on some winter-active Chironomidae. Norsk. Entomol. Tisdsskr., 20: 253-257.

Hanski, I. 1988. Four kind of extra long diapause in insects: A review of theory and observations. Ann. Zool. Fennici, 25: 37-53.90

Hayes, B.P. \& D.A. Murray. 1987. Species composition and emergence of Chironomidae (Diptera) from three high arctic streams on Bathurst Island, Northwest Territories, Canada. Entomol. scand. Suppl., 29: 355-360.

Hodkinson, I.D., S.I. Coulson, N.R. Webb, W. Block, A.T. Strathdee, J.S. Bale, M.R. Worland. 1996. Temperature and the biomass of flying midges (Diptera: Chironomidae) in the high Arctic. Oikos, 75: 241-248.

Klein, B. \& K. Tockner. 2001. Biodiversity in springsbrooks of a glacial flood plain (Val Roseg, Switzerland). Verh. int. Ver. Limnol., 27: 704-710.

Kohshima, S. 1984. A novel cold-tolerant insect found in a Himalayan glacier. Nature, 310: 225-227.

Kownacki, A. 1985. Effect of droughts on the invertebrate communities of high mountain streams. Verh. int. Ver. Limnol., 22: 2069-2072.

Krno, I., F. Šporka, E. Štefková, E. Tirjaková, P. Bitušík, E. Bulánková, J. Lukáš, D. Illéšová, T. Derka, J. Tomajka, J. Černy. 2000. Energy flow in the ecosystem of the high montane stream (Hincov potok, The High Tatra Mts.). Int Symp. High mountain lakes and streams, Innsbruck (Austria). Abstract book: 56-57.

Irons, J.G. III, L.K. Miller \& M.K. Oswood. 1993. Ecological adaptations of aquatic macroinvertebrates to overwintering in interior Alaska (U.S.A.) subarctic streams. Can. J. Zool., 71: 98-108.

Lee, R.E. Jr. 1989. Insect cold-hardiness: to freeze or not to freeze. BioScience, 39(5): 308-313.

Lee, R.E. Jr. \& D.L. Denlinger (Eds). 1991. Insects at low temperature. Chapman \& Hall, New York: 513 pp.

Lencioni, V. 2000. Chironomid (Diptera: Chironomidae) assemblages in three Alpine glacial systems. Ph.D. Thesis, The University of Innsbruck (Austria): 202 pp.

Lencioni, V. \& B. Maiolini. 2002. L'ecologia di un ecosistema acquatico alpino (Val de la Mare, Parco Nazionale dello Stelvio). Natura alpina, 54(4): 1-96.
Lencioni, V., A. Boscaini, A. Franceschini \& B. Maiolini. 2001. Distribuzione di macroinvertebrati bentonici in torrenti d'alta quota sulle alpi italiane: stato delle conoscenze e recenti risultati. Atti S.It.E., 25 (CD-ROM, paper n.42).

Lillehammer, A. 1987. Diapause and quiescence in eggs of Systellognatha stonefly species (Plecoptera) occurring in alpine areas of Norway. Annls Limnol., 23: 179-184.

Lods-Crozet, B., V. Lencioni, J.S. Olafsson, D.L. Snook, G. Velle, J.E. Brittain, E. Castella \& B. Rossaro. 2001a. Chironomid (Diptera: Chironomidae) succession in six European glacial streams. Freshwat. Biol., 46(12): 1791-1809.

Lods-Crozet, B., E. Castella, D. Cambin, C. Ilg, S. Knispel \& H. Mayor-Siméant. 2001b. Macroinvertebrate community structure in relatation to environmental variables in a Swiss glacial stream. Freshwat. Biol., 46(12): 1641-1661.

Maiolini, B. \& V. Lencioni. 2001. Longitudinal distribution of macroinvertebrate community assemblages in a glacially influenced system in the Italian Alps. Freshwat. Biol., 46(12): 1625-1639.

Malard, F., K. Tockner, M-J. Dole-Oliver \& J.V. Ward. 2002. A landscape perspective of surface-subsurface hydrological exchanges in river corridors. Freshwat. Biol., 47: 621640.

Mani, M.S. 1962. Introduction to high altitude entomologyInsect life above the timber-line in the North-Westr Himalaya. Methuen \& Co., Ltd., London: 302 pp.

Mani, M.S. 1968. Ecological specializations of high altitude insects. In: Mani M.S. (Ed.), Ecology and biogeography of high altitude insects. The Hague, Dr. W. Junk: 51-74.

Moore, M.V. \& R.E. Lee Jr. 1991. Surviving the big chill: overwintering strategies of aquatic and terrestrial insects. Am. Entomol., 37: 111-118.

Nagell, B. \& J.E. Brittain. 1977. Winter anoxia - a general feature of ponds in cold temperature regions. Int. Revue ges. Hydrobiol., 62: 821-824.

Økland, B. 1991. Laboratory studies of egg development and diapause in Isoperla obscura (Plecoptera) from a mountain stream in Norway. Freshwat. Biol., 25: 485-495.

Oliver, D.R. 1968. Adaptations of Arctic Chironomidae. Ann. Zool. Fennici, 5: 111-118.

Oliver, D.R. 1971. Life hystory of the Chironomidae. Ann. Rev. Entomol., 16: 211-230.

Olsson, T.I. 1981. Overwintering of benthic macroinvertebrates in ice and frozen sediment in a north Swedish river. Holarct. Ecol., 4: 161-166.

Oswood, M.W., L.K. Miller \& J.G. III Irons. 1991. Overwintering of freshwater benthic macroinvertebrates. In: R.E., Jr., Lee \& D.L. Denlinger (Eds). Insects at low temperature. Chapman and Hall, New York: 360-375.

Ring, R. 1982. Freezing-tolerant insects with low supercooling points. Comp. Biochem. Physiol., 73A(4): 605-612.

Robinson, C.T., U. Uehilnger \& M. Hieber. 2001. Spatio-temporal variation in macroinvertebrate assemblages of glacial streams in the Swiss Alps. Freshwat. Biol., 46(12): $1663-1672$.

Rossaro, B. 1991. Chironomids and water temperature. Aquatic Insects, 13(2): 87-98.

Sæther, O.A. 1968. Chironomids of the Finse area (Norway) with special reference to their distribution in a glacier brook. Arch. Hydrobiol., 64: 426-483.

Salt, R.W. 1961. Principles of insect cold hardiness. Ann. Rev. Entomol., 6: 55-74.

Sømme, L. 1986. Tolerance to low temperatures and desiccation in insects from Andean Paramos. Arctic and Alpine Research, 18(3): 253-257.

Snook, D.L. 2000. Macroinvertebrate communities in alpine glacier-fed streams: the Taillon catchment in the French Pyrénées. Ph.D. Thesis, The University of Birmingham (UK): $192 \mathrm{pp}$.

Snook, D.L. \& A.M. Milner. 2001. The influence of glacial runoff on stream macroinvertebrate communities in the 
Taillon catchment, French Pyrénées. Freshwat. Biol., 46(12): 1609-1623.

Stanford, J.A. \& J.V. Ward. 1988. The hyporheic habitat of river ecosystems. Nature, 335: 64-66.

Stanford, J.A. \& J.V. Ward. 1993. An ecosystem perspective of alluvial rivers: connectivity and the hyporheic corridor. J. N. Am. Benthol. Soc., 12: 48-60.

Steffan, A.W. 1971. Chironomid (Diptera) biocenoses in Scandinavian glacier brooks. Canad. Ent., 103(3): 477486.

Stevens, G.C. 1992. The elevational gradient in altitudinal range: an extension of Rapoport's latitudinal rule to altitude. Am. Nat., 140(6): 893-911.

Storey, K.B. 1990. Biochemical adaptation for cold hardiness in insects. Phil. Trans. R. Soc. Lond., B 326: 635-654.

Strathdee, A.T. \& J.S. Bale. 1998. Life on the edge: insect ecology in arctic environments. Ann. Rev. Entomol., 43: $85-106$.
Ward, J.V. 1994. Ecology of alpine streams. Freshwat. Biol., 32: 277-294.

Ward, J.V. \& J.A. Stanford. 1982. Thermal responses in the evolutionary ecology of aquatic insects. Ann. Rev. Entomol., 27: 97-117.

Ward, J.V., F. Malard, K. Tockner \& U. Uelingher. 1999. Influence of ground water on surface water conditions in a glacial flood plain of the Swiss Alps. Hydrol. Process., 13: 277-293.

Zwick, P. 1981. Diapause development of Protonemura intricata (Plecoptera: Nemouridae). Verh. int. Ver. Limnol., 21: 1607-1611.

Zwick, P. 1999. Egg diapause, egg swelling and mother-child size relationships in Plecoptera (Insecta). Arch. Hydrobiol. Spec. Issues Advanc. Limnol., 54: 373-386. 